\title{
Interaction of Radionuclides with Organic Matter Dissolved in Seawater
}

\author{
- Interaction of Radiocobalt with Some Amino Acids-
}

\author{
Yuichiro KIMURA and Yoshihide HONDA \\ Department of Nuclear Reactor Engineering, Faculty of Science \\ and Technology, Kinki University, \\ Higashi-Osaka, Osaka, Japan \\ Received June 14, 1976
}

\begin{abstract}
The interaction of radiocobalt with glycine, alanine or aspartic acid dissolved in seawater was investigated by means of adsorption on Chelex 100, solvent extraction with dithizone or gel filtration chromatography.

Although the distribution coefficients of Co on Chelex 100 decreased gradually with ageing even in the absence of organic matter, much more decreases were observed in the presence of the amino acids. The distribution coefficients on the resin reached equilibrium states in about 20 days.

The extraction of cobalt with dithizone in carbon tetrachloride was also inhibited in the presence of the amino acids. Alanine and aspartic acid showed a similar interfering tendency in both adsorption on Chelex 100 and dithizone extraction, while glycine inhibited dithizone extraction more than adsorption on Chelex 100.

From the fractionation of Co by Sephadex G-10 gel filtration chromatography, the higher molecular species of Co associated with the amino acids occurred after several days ageing and then increased together with decreasing in the lower molecular species.
\end{abstract}

\section{Introduction}

It is known that radiocobalt such as ${ }^{58} \mathrm{Co}$ and ${ }^{60} \mathrm{Co}$ are among the major neutroninduced radionuclides occurred in the cooling water from nuclear power reactors. Although the levels of radiocobalt are quite low in areas contaminated by reactor effluents, through the accumulation by aquatic biota, ${ }^{60} \mathrm{Co}$ which has relatively long halflife of 5.3 years might possibly become critical in radioactive waste disposal operations. The physico-chemical states of radionuclides in seawater is of fundamental importance to redistribution and the uptakes by organisms. Some informations on the physico-chemical characteristics of cobalt in seawater have been obtained. Sillen ${ }^{1}$ assumed the co-existence of $\mathrm{Co}^{2+}$ and solid $\mathrm{CoOOH}$ in equilibrium on the basis of the solubility equilibrium in seawater. Mara- zović, et $\mathrm{al}^{2), 3)}$ and Honda, et al.4),5) suggested that most of cobalt occurs as a simple cation within few days ageing in seawater by means of electrodialysis and paper electrophoresis. Fukai, et a1.6) showed that divalent cations of cobalt are stable at the $\mathrm{pH}$ of seawater, unless the seawater contains sufficient adsorbents. Although these considerations and experimental facts are not sufficient to determine the chemical form of cobalt in seawater medium, they indicate that divalent cation and/or its hydrolyzed form may be present.

On the other hand, it was pointed out that the considerable part of cobalt in the marine environment was associated with the sediments and the transport of cobalt might be influenced by organic matter in seawater ${ }^{7)}$. Duursma ${ }^{8)}$ reported the interfering effect of leucine on the adsorption of cobalt on marine sediments. Suzuki and Ikeda $^{9)}$ also 
reported that the inhibitive effect of amino acids such as glycine, alanine, leucine, aspartic acid and glutamic acid on the adsorption of cobalt on marine sediments and on an usual cation exchanger was dominated by the chelate formation constant of amino acid with cobaltous ions. Fukai and Murray $^{10)}$ demonstrated the occurrences of some forms of organic cobalt in seawater as well as cyanocobalamin which is well-known organic cobalt compound in natural waters. However, the chemical nature of organic compounds involved and the mechanisms of the formation of organic-metal compounds and their physico-chemical features have not yet been clearly understood.

The present paper deals with the interaction of cobalt with some amino acids such as glycine, alanine and aspartic acid which occur usually in seawater, by means of adsorption on chelating resin, solvent extraction with dithizone and gel filtration chromatography.

\section{Experimental}

\subsection{Materials}

Radiocobalt:

${ }^{60} \mathrm{Co}, \mathrm{CoCl}_{2}$ in $1.5 \mathrm{~N}$ hydrochloric acid solution, specific activity $95 \mathrm{mCi} / \mathrm{mg}, \quad 5.6$ $\mathrm{mCi} / \mathrm{m} l$, as supplied by the Japan Radioisotope Association.

\section{Seawater:}

Artificial seawater was prepared according to the receipt of Lyman and Fleming ${ }^{11)}$. The chlorinity of the seawater is $19.00 \%$. The seawater was filtered using $0.45 \mu \mathrm{m}$ membrane filters prior to use. The $\mathrm{pH}$ of the seawater was adjusted to $8.1 \pm 0.2$ with $0.1 \mathrm{~N}$ sodium carbonate solution.

Chelating resin:

The Chelex 100, sodium form, 100-200 mesh was obtained from Bio-Rad Laboratories of Richmond, California. The exchange capacity was estimated to be 3.0 meq for $\mathrm{Co}^{2+}$ per $1 \mathrm{~g}$ of oven dried resin. The resin was washed 3 times with distilled water and then equilibrated with the artificial seawater.

Dextran gel:
The Sephadex G-10, particle size 40-120 $\mu \mathrm{m}$, produced by Pharmacia Fine Chemicals, Uppsala was used. The nominal molecular weight exclusion limit for this material is 700.

Chemicals:

All chemicals used in the experiments were of the reagent quality.

\subsection{Experimental procedures}

The following experimental systems were constructed.

(1) seawater $+{ }^{60} \mathrm{Co}$, (control),

(2) seawater + glycine hydrochloride $50 \mathrm{mg} /$

$l, 4.48 \times 10^{-4} \mathrm{M}+{ }^{60} \mathrm{Co}$,

(3) seawter $+l-\alpha$-alanine $50 \mathrm{mg} / l, 5.61 \times 10^{-4}$ $M+{ }^{60} \mathrm{Co}$,

(4) seawater $+l$-aspartic acid $50 \mathrm{mg} / l, 3.76 \times$ $10^{-4} M+{ }^{60} \mathrm{Co}$

Two hundred $\mathrm{m} l$ each of the above mentioned seawater was poured into 4 flasks (the content $300 \mathrm{ml}$ each). Each flask was capped to prevent the evaporation of seawater and continuously aerated at a flow rate of about $100 \mathrm{ml} / \mathrm{min}$ at the temperature of $15 \pm 2^{\circ} \mathrm{C}$. The final concentration of cobalt carrier in each system was about $10^{-i} M$. An aliquot of the seawater samples was taken for assay at appropriate time intervals during ageing.

Adsorption of cobalt on Chelex 100:

The batch technique was used. To a 50 $\mathrm{m} l$ glass centrifuge tube were added $1 \mathrm{~m} l$ of Chelex 100 ( $0.32 \mathrm{~g}$ of dry weight) and $5 \mathrm{ml}$ of the seawater sample. The mixture was stirred for 1 hour, and then centrifuged. One $\mathrm{m} l$ of the supernate was analyzed by gross gamma counting. The results are expressed in terms of the distribution coefficient $\left(K_{d}\right)$. The $K_{d}$ is represented by the formulation,

$$
K_{a}=\frac{C_{0}-C}{C} \times \frac{V}{G}
$$

where $C_{0}$ is the activity in the seawater solution before equilibrium (cpm), $C$ is the activity in the supernate after equilibrium (cpm), $V$ is the volume of the seawater solution $(\mathrm{m} l), G$ is the dry weight of the resin introduced into the system $(g)$.

The percentage adsorption is given by 


$$
\% \text { Adsorption }=\frac{C_{0}-C}{C_{0}} \times 100
$$

Extraction of cobalt with dithizone in carbon tetrachloride ${ }^{12)}$ :

To a separatory funnel were added $5 \mathrm{ml}$ of the seawater sample and $1 \mathrm{~m} l$ of $5.88 \%$ $(\mathrm{w} / \mathrm{v})$ sodium citrate solution and then the mixture was diluted to $15 \mathrm{~m} l$ with distilled water. Cobalt was extracted into $10 \mathrm{ml}$ of carbon tetrachloride containing $0.05 \%$ dithizone for 30 minutes. The extraction was repeated 3 times.

The percentage extraction is given by

$$
\% \text { Extraction }=\frac{A_{0}-A}{A_{0}} \times 100
$$

where $A_{0}$ is the activity in the aqueous phase before extraction (cpm), $A$ is the activity in the aqueous phase after 3 times extraction (cpm).

Gel filtration chromatography:

The chromatography column (15 $\phi \times 830$ $\mathrm{mm}$ ) was equilibrated with filtered artificial seawater at room temperature. One $\mathrm{m} l$ each of the seawater sample was applied and then the sample was eluted by downward flow with the filtered seawater at a flow rate of $20 \mathrm{ml} / \mathrm{h}$

Each $5 \mathrm{~m} l$ of the effluent was collected using fraction collector Model SF-160K manufactured by Toyo Sangyo Co. Ltd. An aliquot of each effluent was analyzed by gross gamma counting and spectrophotometry for amino acids and Blue Dextran which were used for column calibration. The $K_{d}$ values for fractionated cobalt is represented by the formulation,

$$
K_{d}=\frac{V_{S}-V_{\text {B.D. }}}{V_{\text {THO }}-V_{\text {B.D. }}}
$$

where $V_{S}$ is the effluent volume of ${ }^{60} \mathrm{Co}(\mathrm{m} l)$, $V_{\text {B.D. }}$ is the effluent volume of Blue Dex$\operatorname{tran}(\mathrm{m} l), V_{\text {тно }}$ is the effluent volume of tritiated water $(\mathrm{m} l)$.

Measurement of activity:

The activity of each sample was measured using Auto-well gamma system Model JDC-752 manufactured by Aloka Co. Ltd. The standard deviation of each measurement was less than $10 \%$.

Spectrophotometry:
Hitachi Perkin-Elmer Spectrophotometer Model 139 was used.

\section{Results and Discussion}

3.1 Adsoption of cobalt on Chelex 100

The changes of the values of distribution coefficient $\left(K_{d}\right)$ of cobalt on Chelex 100 as a function of ageing time of cobalt in the seawater are shown in Fig. 1.

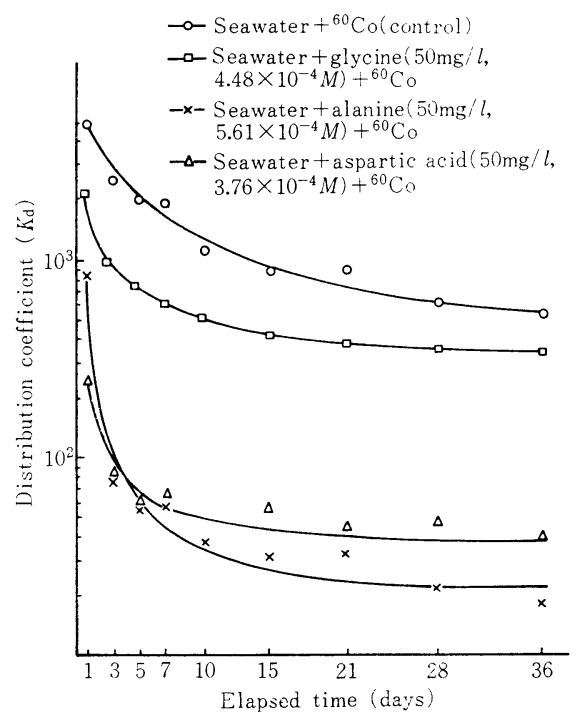

Fig. 1 Changes of $K_{d}$ values of ${ }^{60} \mathrm{Co}$ on Chelex 100 as a function of ageing time.

Although the $K_{d}$ values decreased with ageing time even in the control seawater, much more decreases in the $K_{d}$ values were observed in the presence of amino acids such as glycine, alanine and aspartic acid in the seawater. These decreases trended gradually toward equilibrium in about 20 days.

On the other hand, the percentage adsorption of cobalt in the control was more than 97\% during 36 days ageing, while those of cobalt in the presence of glycine, alanine and aspartic acid were $85.5 \%, 54.1 \%$ and 72.0 $\%$ in 36 days, respectively (Table 1).

The Chelex 100 has an unusually high preference for copper, cobalt and other heavy metals over such cations as sodium, potassium, magnesium and calcium which are major cations in seawater ${ }^{13)}$. The sodium form of Chelex 100 is represented by 
Table 1 Interfering effects of amino acids on the adsorbtion and extraction of radiccobalt in seawater

(After 36 days ageing)

\begin{tabular}{l|c|c|c|c}
\hline \multirow{2}{*}{ Amino acid } & \multicolumn{2}{|c|}{ Adsorption on Chelex 100} & \multicolumn{2}{c}{ Extraction with dithizone } \\
\cline { 2 - 3 } & Retained & Not retained & Extracted & Not extracted \\
\hline 0 (control) & 97.2 & 2.8 & 97.5 & 2.5 \\
\hline Glycine $4.48 \times 10^{-4} M$ & 85.5 & 14.5 & 51.4 & 48.6 \\
\hline Alanine $5.61 \times 10^{-4} M$ & 54.1 & 45.9 & 55.7 & 44.3 \\
\hline Aspartic acid $3.76 \times 10^{-4} M$ & 72.0 & 28.0 & 74.9 & 25.1 \\
\hline
\end{tabular}

the formulation,

$$
\mathrm{R}-\mathrm{N}\left\langle\begin{array}{l}
\mathrm{CH}_{2}-\mathrm{COO}^{-} \mathrm{Na}^{+} \\
\mathrm{CH}_{2}-\mathrm{COO}^{-} \mathrm{Na}^{+}
\end{array}\right.
$$

where $\mathrm{R}$ represents the co-polymer matrix. Coordination takes place between the two carboxyl groups and tertiary nitrogen. Thus cobalt ions are converted to chelate compounds in contact with Chelex 100. Lowman and Ting $^{14)}$ reported that the chelating resin, Chelex 100 retained only $0.6 \%$ of the organically bound cobalt such as cyanocobalamin and $91 \%$ of the ionic forms. Callahan, et al. ${ }^{15)}$ also suggested that the $\mathrm{Co}(\mathrm{III})$ is tied up as a strong complex and is not available for exchange by the chelating resin. As indicated by them ${ }^{15)}, \mathrm{Co}^{3+}$ is unstable towards reduction in an acid environment, whereas $\mathrm{Co}^{2+}$ is air-oxidized to $\mathrm{Co}^{3+}$ in an alkaline medium. The $\mathrm{pH}$ of seawater (7.8-8.2) would tend to favor the oxidation of cobalt. Loewenschuss, et al. ${ }^{16)}$ demonstrated that the chelating resin Dowex A-1 which has an iminodiacetic acid (IDAA) similar to Chelex 100 as a chelating group could form the mixed metal-ligand-resin complexes as well as metal-resin complexes. The reactions are represented by the following formulas,

$$
\begin{aligned}
& \mathrm{M}+\mathrm{L} \rightleftharpoons \mathrm{ML} \\
& \mathrm{ML}+\mathrm{R} \rightleftharpoons \mathrm{MLR}
\end{aligned}
$$

where $M$ is metal ions in the solution, $L$ is ligands in the solution, ML is metal-ligand complexes, $\mathbf{R}$ is chelating resin, MLR is mixed metal-ligand resin complexes. However, metal ions bound to a large polydentate ligand, such as EDTA or the like, which, because of its bulky molecules and the ster- eospecificity of its complexes, will not enter the resin, as did IDAA or glycine ${ }^{16)}$. As discussed above, some organic cobalt complexes, especially in the case of cobalt glycinate might be retained by the resin.

On the other hand, the unsorbed fraction of cobalt in the control seawater which is free from dissolved organic matter, might be attributed to possible hydrolytic products of cobalt in the seawater medium, since the hydrolysis of cobalt might form electroneutral and/or negative charged products ${ }^{17}$.

3.2 Extraction of cobalt with dithizone in carbon tetrachloride

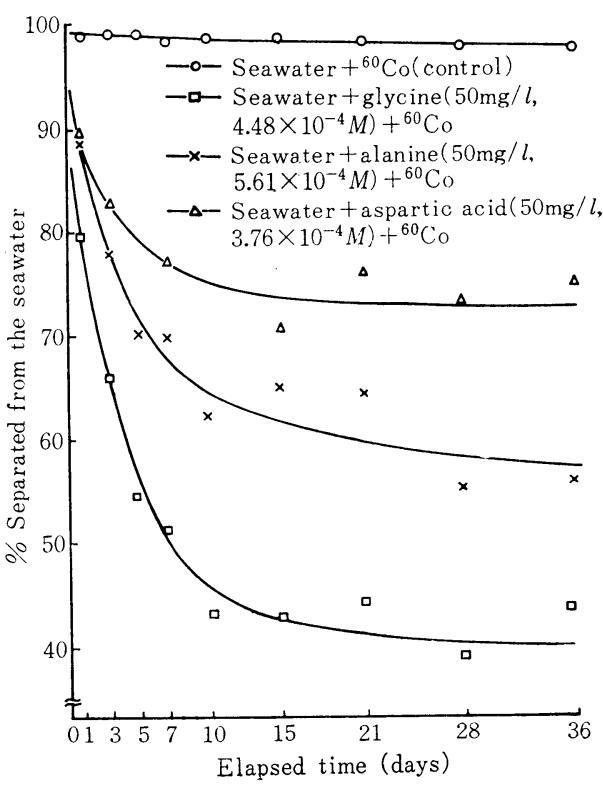

Fig. 2 Extraction of ${ }^{60} \mathrm{Co}$ with dithizone in carbon tetrachloride. 
The results of the extraction of cobalt from the seawater with dithizone in carbon tetrachloride are shown in Fig. 2.

From these results, more than $97 \%$ of cobalt in the control seawater was extracted in 36 days ageing, while the percentages of extraction of cobalt in the presence of the amino acids decreased with ageing time and gradually trended toward equilibrium. Lowman and Ting ${ }^{14)}$ reported that the extraction of cobalt into dithizone in organic solvent removed only $1.3 \%$ of the cyanocobalamin from seawater, but extracted $97 \%$ of the ionic cobalt.

Compared the results from the solvent extraction with those from the adsorption on the chelating resin, a similar interfering tendency was observed in both alanine and aspartic acid, while in the case of glycine, somewhat different result was obtained. Namely, the interfering effect of glycine on the extraction of cobalt with dithizone was greater than that on the adsorption on the chelating resin (Table 1). This fact might be attributed to the possibility of the formation of cobalt-glycine-resin complexes. Taking account of the stability constants of cobalt (II) complexes with the amino acids and dithizone $\left(\log K_{1} K_{2}\right.$ : aspartic acid $>$ glycine $\gtrsim$ alanine $>$ dithizone $)^{18)}$, the cobalt complexes with the amino acids are more
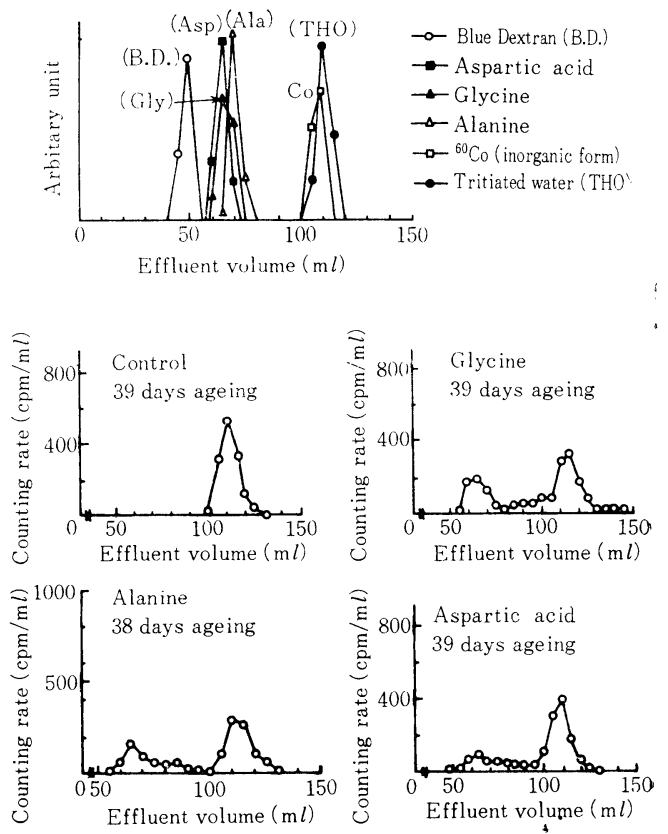

Fig. 3 Fractionation of ${ }^{60} \mathrm{Co}$ by gel filtration chromatography.

Table 2 Fractionation of radiocobalt in seawater by Sephadex G-10 gel chromatography

(Column size: $15 \phi \times 830 \mathrm{~mm}$ )

Flow rate $: 20 \mathrm{ml} / \mathrm{h}$

\begin{tabular}{|c|c|c|c|c|c|c|c|c|c|c|c|}
\hline \multicolumn{3}{|c|}{ Control } & \multicolumn{3}{|c|}{$\begin{array}{c}\text { Glycine } \\
4.48 \times 10^{-4} M\end{array}$} & \multicolumn{3}{|c|}{$\begin{array}{c}\text { Alanine } \\
5.61 \times 10^{-4} M\end{array}$} & \multicolumn{3}{|c|}{$\begin{array}{l}\text { Aspartic acid } \\
3.76 \times 10^{-4} M\end{array}$} \\
\hline $\begin{array}{l}\text { Ageing } \\
\text { time } \\
\text { (days) }\end{array}$ & $K_{d}$ & $\begin{array}{c}\text { Recovery } \\
(\%)\end{array}$ & $\begin{array}{l}\text { Ageing } \\
\text { time } \\
\text { (days) }\end{array}$ & $K_{d}$ & $\begin{array}{c}\text { Recovery } \\
(\%)\end{array}$ & $\begin{array}{l}\text { Ageing } \\
\text { time } \\
\text { (days) }\end{array}$ & $K_{d}$ & $\begin{array}{l}\text { Recovery } \\
(\%)\end{array}$ & $\begin{array}{l}\text { Ageing } \\
\text { time } \\
\text { (days) }\end{array}$ & $K_{d}$ & $\begin{array}{l}\text { Recovery } \\
(\%)\end{array}$ \\
\hline 2 & 1.0 & 93.8 & 1 & $\begin{array}{l}0.3 \\
1.1\end{array}$ & $\begin{array}{r}0.9 \\
84.5\end{array}$ & 1 & 1.0 & 86.9 & 2 & $\begin{array}{l}0.4 \\
1.0\end{array}$ & $\begin{array}{r}1.9 \\
88.6\end{array}$ \\
\hline 4 & 1.0 & 98.0 & 3 & $\begin{array}{l}0.3 \\
1.0 \\
\end{array}$ & $\begin{array}{r}4.2 \\
84.2 \\
\end{array}$ & 3 & 1.0 & 89.6 & 4 & $\begin{array}{l}0.3 \\
1.0\end{array}$ & $\begin{array}{r}5.2 \\
86.2 \\
\end{array}$ \\
\hline 8 & 1.0 & 96.7 & 7 & $\begin{array}{l}0.2 \\
1.0 \\
\end{array}$ & $\begin{array}{r}8.9 \\
73.7 \\
\end{array}$ & 7 & $\begin{array}{l}0.3 \\
1.0\end{array}$ & $\begin{array}{l}10.5 \\
72.8\end{array}$ & 8 & $\begin{array}{l}0.3 \\
1.0\end{array}$ & $\begin{array}{r}6.8 \\
78.3 \\
\end{array}$ \\
\hline 11 & 1.1 & 99.3 & 10 & $\begin{array}{l}0.2 \\
1.0\end{array}$ & $\begin{array}{l}15.3 \\
55.7\end{array}$ & 10 & $\begin{array}{l}0.3 \\
1.0\end{array}$ & $\begin{array}{l}14.0 \\
63.0\end{array}$ & 11 & $\begin{array}{l}0.3 \\
1.1\end{array}$ & $\begin{array}{r}8.6 \\
60.0\end{array}$ \\
\hline 18 & 1.1 & 93.2 & 17 & $\begin{array}{l}0.3 \\
1.2\end{array}$ & $\begin{array}{l}19.9 \\
50.5\end{array}$ & 17 & $\begin{array}{l}0.3 \\
1.0\end{array}$ & $\begin{array}{l}13.1 \\
75.5\end{array}$ & 18 & $\begin{array}{l}0.3 \\
1.2\end{array}$ & $\begin{array}{l}10.4 \\
65.9\end{array}$ \\
\hline 25 & 1.0 & 96.5 & 24 & $\begin{array}{l}0.2 \\
1.2\end{array}$ & $\begin{array}{l}23.6 \\
42.2\end{array}$ & 24 & $\begin{array}{l}0.3 \\
1.0\end{array}$ & $\begin{array}{l}22.1 \\
58.8\end{array}$ & 25 & $\begin{array}{l}0.3 \\
1.2\end{array}$ & $\begin{array}{l}11.0 \\
61.8\end{array}$ \\
\hline 32 & 1.0 & 94.7 & 31 & $\begin{array}{l}0.2 \\
1.2\end{array}$ & $\begin{array}{l}27.4 \\
40.9\end{array}$ & 38 & $\begin{array}{l}0.3 \\
1.0\end{array}$ & $\begin{array}{l}29.0 \\
48.0\end{array}$ & 32 & $\begin{array}{l}0.3 \\
1.1 \\
\end{array}$ & $\begin{array}{l}12.6 \\
62.9\end{array}$ \\
\hline 39 & 1.2 & 92.1 & 38 & $\begin{array}{l}0.2 \\
1.2 \\
\end{array}$ & $\begin{array}{l}29.2 \\
50.6\end{array}$ & 43 & $\begin{array}{l}0.3 \\
1.0 \\
\end{array}$ & $\begin{array}{l}24.2 \\
60.4\end{array}$ & 39 & $\begin{array}{l}0.3 \\
1.2\end{array}$ & $\begin{array}{l}15.1 \\
57.3\end{array}$ \\
\hline
\end{tabular}

Standard deviation of $K_{d}$ value: \pm 0.1

Standard deviation of recovery: $<10 \%$ 
stable than cobalt dithizone complex. Therefore, the cobalt complexes with the amino acids would not be extracted with dithizone in carbon tetrachloride.

3.3 Gel filtration chromatography of cobalt

The elution profiles of cobalt through the Sephadex G-10 columns as well as those of Blue Dextran, tritium and the amino acids which were used for column calibration are shown in Fig. 3.

As can be seen in Fig. 3, the organic cobalt supposed to be associated with the amino acids was separated from the inorganic cobalt according to their molecular size under similar conditions to those of the complex formation. The significant quantities of the higher molecular cobaltbinding species occurred after several days ageing and then increased together with decreasing in the lower molecular species (Table 2).

As stated by $\mathrm{Fukai}^{10)}$ these results suggest that the complex formation of ionic cobalt with soluble organic matter in seawater proceeds at a slow rate, unless heterogeneous surfaces such as inorganic particles or detritus where the reactants are highly concentrated, are involved. The fact that the $K_{d}$ values of the lower molecular species of cobalt in the seawater exceeded unity, indicates the adsorption effect of cobalt onto the gel in addition to the sieving effect.

\section{References}

1) Sillen, L.G.: The physical chemistry of sea water. In "Oceanography" (M. Sears Ed.) Publ. No. 67, 549, Amer. Assoc. Adv. Sci., Washington, D.C. (1961)

2) Marazović, Lj. and Pučar, Z.: Croat. Chem. Acta, 38, 183 (1966)

3) Marazović, Lj. and Pucăr, Z.: J. Chromatog., 27, 450 (1967)
4) Honda, Y., Kimura, Y. and Tsurii, N.: Radioisotopes, 21, 269 (1972)

5) Honda, Y.: NIRS-M-10 (Proc. 2nd NIRS Seminar, Chiba), 27 (1975)

6) Fukai, R., and Huynh-Ngoc, L.: Radioactivity in the sea series, Publ. No. 22, 26, IAEA, Vienna (1968)

7) Krauskopf, K.B.: Geochim. et Cosmochim. Acta, 9, 1 (1956)

8) Duursma, E.K.: "Organic Matter in Natural Waters", University of Alaska (1970)

9) Suzuki, E. and Ikeda, N.: Radioisotopes, 23, 373 (1974)

10) Fukai, R., Murray, C.N.: Environmental Behaviour or Radionuclides Released in the Nuclear Industry, 217 (IAEA-SM-72/42), IAEA, Vienna (1973)

11) Lyman, J. and Fleming, R.H.: J. Mar. Res., 3, 134 (1940)

12) Sandell, E.B.: Colorimetric Determination of Traces of Metals, 410, Interscience Publishers Inc., New York (1959)

13) Samuelson, O.: Ion Exchange Separation in Analytical Chemistry, John Wiley and Sons Inc., New York (1963)

14) Lowman, F.G., Ting, R.Y.: Radioactive Contamination of the Marine Environment (Proc. Symp. Seattle, 1972), 369 (IAEA-SM-158/23), IAEA, Vienna (1973)

15) Callahan, C.M., Pascual, J.M., Lai, M.G.: USNRDL-TR-67-10 (1966)

16) Loewenschuss, H. and Schmuckler, G.: Talanta, 11, 1399 (1964)

17) Stalik, I.E.: "Fundamentals of Radiochemistry" (Translated into Japanese by Ichikawa, Okashita and Ishiwatari), Nankodo, Tokyo (1962)

18) Martell, A.E.: Stability Constants of Metal-Ion Complexes, Section II, The Chemical Society, Burlington House (1964) 
要 旨

\title{
放射性核種と海水中溶存有機物質との相互作用
}

\author{
一放射性コバルトとニ，三のアミノ酸との相互作用一 \\ 木村雄一郎, 本田嘉秀 \\ 近畿大学理工学部原子炬工学科 \\ 東大阪市
}

\begin{abstract}
放射性コバルトと海水中に溶存しているグリシン，アラニン扣よびアスパラギン酸との相互作用 をキレックス 100 への吸着, ジチゾンによる溶媒抽出扰よびゲルろ過クロマトグラフィによって研 究した。

キレックス 100 へのコバルトの分配係数は有機物質の存在しない場合でもェージングとともに徐 々に減少したが,これらのアミノ酸の存在する場合にはいっそうの減少がみられた。樹脂への分配 係数は約 20 日間で平衡状態になった。

ジチゾンによるコバルトの四塩化炭素への抽出もまたこれらのアミノ酸の存在によって阻害され た。

アラニンおよびアスパラギン酸はキレックス 100 への吸着扰よびジチゾン抽出の両法に扰いて， 同じような阻害傾向を示したが, グリシンはキレックス 100 への吸着よりるジチゾン抽出を多く阻 害した。

セファデックス G-10ゲルろ過クロマトグラフィによるコバルトの分画では，これらのアミノ酸 と結合したコバルトの高分子種は数日間のエージングののちに出現し, その後低分子種の減少をと もないながら増加した。
\end{abstract}

